\title{
Uji Kemiripan Kalimat Judul Tugas Akhir dengan Metode Cosine Similarity dan Pembobotan TF-IDF
}

\author{
Indra Mawanta, T S Gunawan², Wanayumini*
}

Fakultas Teknik dan Ilmu komputer, Prodi Magister Ilmu Komputer, Universitas Potensi Utama, Medan, Indonesia Email: ${ }^{1}$ mawanta29@gmail.com, ${ }^{2}$ tsgunawan@gmail.com, ${ }^{3, *}$ wanayumini@gmail.com

Email Penulis Korespondensi: wanayumini@gmail.com

\begin{abstract}
Abstrak-Institut Kesehatan Deli Husada adalah kampus Kesehatan yang sudah berdiri selama 34 tahun, pada saat ini memiliki mahasiswa berjumlah 30000 mahasiswa, setiap mahasiswa pada tingkat akhir akan melakukan tugas akhir program studi setiap tahunnya, setiap mahasiswa sebelum melakukan laporan tugas akhir wajib memberikan judul laporan tugas akhirnya ke program studi, untuk mengurangi tingkat kesamaan judul laporan akhir mahasiswa, program studi biasanya melakukan cek manual, hasil yang muncul adalah tidak efektif dalam penentua peng judul tugas akhir pada mahasiswa, sehingga menimbilkan kemiripan yang cukup banyak antara mahasiswa. Sehingga banyak laporan tugas akhir yang terlihat sama. Dengan kondisi di atas maka dilakukan Uji Kemiripan Kalimat Judul Tugas Akhir Dengan Metode Cosine Similarity dan Pembobotan TF-IDF Pada Kampus Institut Kesehtaan Deli Husada Delitua.Pada akhir hasil uji coba pada data latih terhadap data training, diperoleh hasil yakni 43\% judul yang diajukan tidak layak untuk diajukan Kembali dan 53\% layak untuk diajukan sebagai judul tugas akhir dikarenakan memiliki kemiripan yang tinggi pada judul laporan tugas akhir. Dan memperoleh rata-rata waktu 0.12117 dalam menit.
\end{abstract}

Kata Kunci: Cosine Similarity; Text Mining; Pembobotan TF-IDF; Laporan Tugas Akhir; Machine Learning

Abstract-Deli Husada Health Institute is a health campus that has been established for 34 years, currently it has 30000 students, each student at the final level will submit a final project of study program every year, each student before doing his final project report must provide the title of an assignment report. Finally, to the study program, to reduce the level of similarity in the title of the student's final report, the study program usually conducts a manual check, the result that appears is that it is not effective in determining the title of the final project for students, so that it creates quite a lot of similarities between students. So that many final project reports look the same. With the above conditions, the Sentence Similarity Test of the Final Project Title was carried out with the Cosine Similarity Method and TF-IDF Weighting at the Deli Husada Delitua Health Institute Campus. At the end of the test results on the training data against the training data, the results obtained were $43 \%$ of the titles in Submitted is not eligible to be submitted again and $53 \%$ is eligible to be submitted as the title of the final project because it has high similarities to the title of the final project report. And get the average time 0.12117 in minutes.

Keywords: Cosine Similarity; Text Mining; TF-IDF Weighting; Final Project Report; Machine Learning

\section{PENDAHULUAN}

Institut Kesehatan Deli usada adalah kampus Kesehatan yang sudah berdiri selama 34 tahun, pada saat ini mahasiswa berjumlah 30000 mahasiswa, setiap mahasiswa pada tingkat akhir akan melakukan tugas akhir program studi setiap tahunnya, setiap mahasiswa sebelum melakukan laporan tugas akhir wajib konsultasi judul laporan tugas akhirnya kepada program studi, untuk tingkat kesamaan judul laporan akhir mahasiswa, program studi biasanya melakukan cek manual, hasil yang muncul adalah tidak efektif dalam penentuan judul tugas akhir pada mahasiswa, sehingga kemiripan yang cukup banyak antara mahasiswa. Sehingga banyak laporan tugas akhir yang terlihat sama. Dengan kondisi di atas maka dilakukan Uji Kemiripan Kalimat Judul Tugas Akhir Dengan Metode Cosine Similarity dan Pembobotan TF-IDF Pada Kampus Institut Kesehtaan Deli usada Delitua.

Metode Cosine Similarity merupakan metode yang dapat melakukan pendeteksian secara cepat dan tepat, cosine similarity juga merupakan salah satu metode yang dapat digunakan untuk mengukur tingkat kemiripan dokumen [1]. Sebelum melakukan perhitungan kemiripan, terhadap beberapa tahap processing text mining yang dilakukan, yaitu tokenizing, stoplist dan stemming[2]. Term hasil proses tersebut direpresentasikan dalam model ruang vector dengan pembobotan TF-IDF, setelah itu, dilakukan perhitungan jarak cosinus antar vector menggunakan cosine similarity. Kemudian pada Artikel selanjutnya menunjukkan bahwa, penerapkan algoritma term frequency inverse-document frequency untuk text mining sangat membantu pengguna. untuk mendapatkan informasi pada kumpulan dokumen. Dengan format file.txt berdasarkankata kunci yang dimasukan oleh pengguna pada sistem. Dengan koleksi uji kata 'upaya' pada query maka didapatkan keluaran dengan bobot nilai 8.65441 yang merupakan jumlah kata terbanyak sesuai dengan query[3]. Penelitian ini sistem untuk mengukur tingkat kemiripan antar dokumen teks berbahasa Indonesia berhasil dibangun menggunakan algoritma Cosine similarity. semakin banyak dokumen yang dibandingkan maka semakin banyak pula waktu yang dibutuhkan. Sebelumnya artikel sistem ini terbilang cukup efektif untuk membantu mahasiswa dalam melakaukan aktivitas skripsi. Hal itu dibuktikan dengan hasil uji coba yang menunjukkan penilaian rata-rata sebesar 8,82 dari nilai range antara 1 sampai 10 dan masuk dalam kategori cukup efektif[4].

Pada artikel ini, peneliti akan melakukan analisis data Uji Kemiripan Kalimat Judul Tugas Akhir Dengan Metode Cosine Similarity dan Pembobotan TF-IDF, yang hasilnya pengguna yaitu program studi dalam pengecekan judul laporan akhir mahasiswa agar mengurangi kemiripan laporan akhir. 
Tujuan uji coba ini berguna untuk program studi dalam keputusan layak atau tidak nya judul laporan tugas akhir mahasiswa. Tersebut untuk di jadikan laporan tugas akhir. Sehingga mengurangi konteks laporan tugas akhir yang sama dan mempercepat waktu pemeriksaan antara judul-judul yang sudah ada dengan judul yang di ajukan pada saat sekarang ini.

\section{METODOLOGI PENELITIAN}

\subsection{Proses Kerja Uji Coba}

Kerangka kerja uji coba penelitian ini secara sistematis yang menuju pada alur proses untuk mendapatkan hasil pada uji coba penelitian ini bisa dilihat pada Gambar 1.

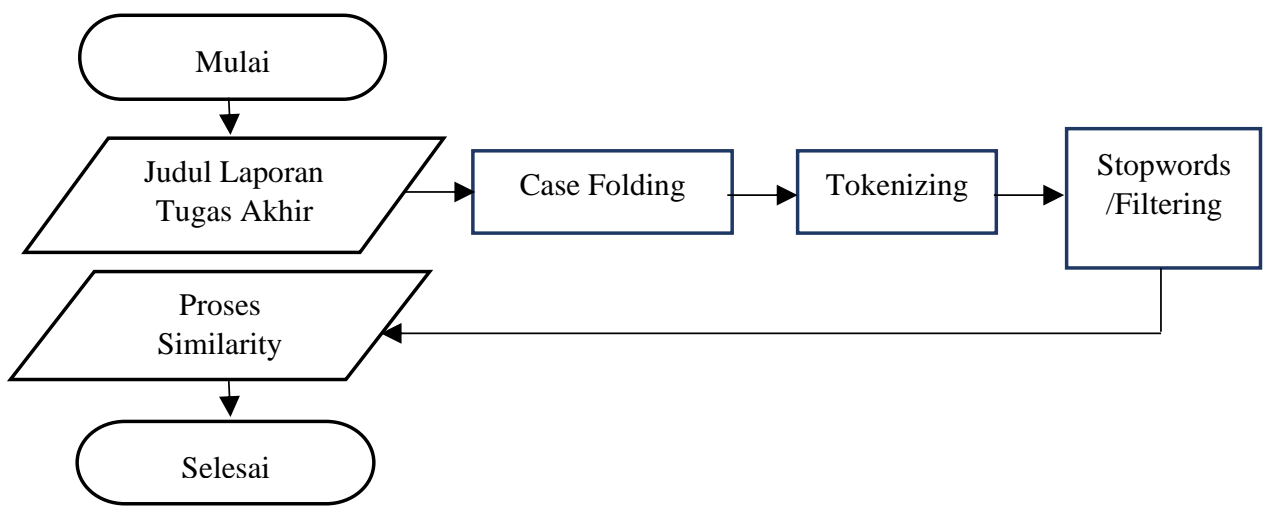

Gambar 1. Alur Proses Uji Coba

Tahap preprocessing yang digunakan dalam penelitian ini [5], antara lain:

1. Case Folding

Merupakan tahap perubahan huruf dari huruf kapital menjadi huruf kecil.

2. Tokenizing

Tokenizing adalah proses memecah dokumen menjadi kumpulan kata[6]. Tokenization dapat dilakukan dengan menghilangkan tanda baca dan memisahkannya per spasi.Tahapan ini juga menghilangkan karakter-karakter tertentu seperti tanda baca dan mengubah semua token ke bentuk huruf kecil (lower case).

3. Stopwords/Filtering

Stopwords removal merupakan proses penghilangan kata tidak penting pada deskripsi melalui pengecekan kata-kata hasil parsing deskripsi apakah termasuk di dalam daftar kata tidak penting (stoplist) atau tidak[6]. Jika termasuk didalam stoplist maka kata-kata tersebut akan di-remove dari deskripsi sehingga kata-kata yang tersisa di dalam deskripsi dianggap sebagai kata-kata penting atau keywords.

4. Tahap Processing

maka data akan disimpan dalam memori sementara dan nantinya akan diproses lebih lanjut ke dalam tahap analyzing menggunakan pembobotan TF-IDF dan klasifikasi dengan algoritma cosine similarity[7].

\subsection{Tahap Term Frequency Inverse Document Frequency $($ TF-IDF) TF}

Term adalah frekuensi kemunculuan kata pada setiapdokumen, dari TF tersebut didapatkan DF (document frequency) yaitu banyaknya dokumen yang mengandung suatu kata tersebut [8]. TF-IDF merupakan sebuah nilai yang digunakan untuk menghitung bobot sebuah kata yang muncul dalam dokumen. TF-IDF didapatkan dari hasil perkalian antar TF dan IDF, di mana IDF merupakan hasil invers dari DF [9]. Perhitungannya dapat dituliskan sebagai berikut:

Keterangan:

$$
\begin{aligned}
& \operatorname{IDF}(\mathrm{W})=\log \left(\frac{n}{D F(W)}\right) \\
& \mathrm{TF}-\operatorname{IDF}(\mathrm{w}, \mathrm{d})=\mathrm{TF}(\mathrm{w}, \mathrm{d}) \mathrm{XIDF}(\mathrm{w})
\end{aligned}
$$

IDF(w) : bobot kata dalam seluruh dokumen, W: sebuah kata, $\mathrm{TF}(\mathrm{w}, \mathrm{d})$ : frekuensi kemunculan kata w dalam dokumen $\mathrm{d}, \mathrm{IDF}(\mathrm{w})$ : inverse $\mathrm{DF}$ dari kata $\mathrm{w}, \mathrm{N} \mathrm{DF}(\mathrm{w})$ : jumlah seluruh dokumen. Jika diperhatikan dari perhitungan IDF rumus nomor 1 , apabila $\mathrm{N}=\mathrm{DF}(\mathrm{w})$ maka akan didapatkan hasil 0 (nol). Untuk menyiasati hal tersebut maka dapat ditambahkan nilai 1 pada sisi IDF, dan perhitungan TF (w,d)

\subsection{Cosine Similarity}

Merupakan ukuran kesamaan antara dua buah vektor dalam sebuah ruang dimensi yang didapat dari nilai cosinus sudut dari perkalian dua buah vektor yang dibandingkan karena cosinus dari 00 adalah 1 dan kurang dari 1 untuk nilai sudut yang lain, maka nilai similarity dari dua buah vektor dikatakan mirip ketika nilai dari cosine similarity 
adalah 1 [2]. Cosine similarity digunakan dalam ruang positif, di mana hasilnya dibatasi antara nilai 0 dan 1 [10]. Kalau nilainya 0 maka dokumen tersebut dikatakan mirip jika hasilnya 1 maka nilai tersebut dikatakan tidak mirip Perhatikan bahwa batas ini berlaku untuk sejumlah dimensi, dan cosine similarity ini paling sering digunakan dalam ruang positif dimensi tinggi. Misalnya, dalam information retrieval, masing-masing kata/istilah (term) diasumsikan sebagai dimensi yang berbeda dan dokumen ditandai dengan vektor di mana nilai masing-masing dimensi sesuai dengan berapa istilah muncul dalam dokumen [7].

\subsection{Text Mining}

Text mining adalah penggalian informasi dari teks oleh user menggunakan tools analisis. Secara umum text mining mengadopsi proses-proses didalam data mining dan didalam text mining juga menggunakan teknik data mining [11].

a. Teks Preprocessing

Proses reduksi teks yang bertujuan membuang kata-kata atau term-term yang tidak memiliki kontribusi atau bobot yang mempengaruhi tahap selanjutnya [12]. Praproses teks diantaranya yakni extraction teks, stemming, stopword removal akan menghasilkan query yang akan digunakan pada tahap selanjutnya.

b. Term Weighting

Term weighting adalah sebuah metode pembobotan kata (term) untuk memberikan sebuah bobot atau nilai untuk kata (term) yang terkandung dalam sebuah dokumen. Bobot nilai ini menjadi ukuran besarnya jumlah dan tingkat kontribusi sebuah kata (term) untuk penentuan suatu kelas atau kategori dalam suatu dokumen. Terdapat beberapa metode pembobotan kata (term weighting) diantaranya adalah TF, TF-IDF, WIDF, dan TF$\mathrm{RF}[13]$.

\section{HASIL DAN PEMBAHASAN}

\subsection{Tahap Uji Coba}

Kalimat judul laporan tugas akhir sebagai dataset melalui tahap awal yaitu preprocessing. Pada tahap preprocessing dokumen dipotong menjadi potongan-potongan kata (tokenizing), dihilangkan kata yang termasuk daftar stoplist (stopword removal), dan dirubah menjadi akar kata (stemming) [14]. Setelah itu, dilakukan pembobotan kata terhadap term hasil tahap preprocessing, mulai dari perhitungan nilai TF (Term Frequency), IDF (Invers Document Frequency).

Untuk melakukan eksperimen, maka diperlukan kerangka kerja (framework) klasifikasi teks atau kalimat pengaduan masyarakat. Susunan kerangka kerja tersebut sebagai berikut:

1. Defining Complaint Set

Terdapat sebanyak 88 kalimat pengaduan masyarakat yang akan dibuktikan dengan eksperimen melalui tahap preprocessing.

2. Word Extraction

Menghilangkan semua tanda baca pada setiap kalimat pengaduan masyarakat.

3. Tokenize Text

Pemotongan string input atau dokumen berdasarkan tiap kata yang menyusunnya.

4. Vector Representation For Text

Setelah proses tokenization kata dan menghapus kata-kata yang tidak sesuai, tahap berikutnya adalah pembobotan fitur menggunakan TF-IDF (Term Frequency-Inverse Document Frequency). Pilihan fitur atau kunci tambahan rekayasa merupakan representasi dari nilai fitur.

5. DF Vector Reduction

Menghitung frekuensi kemunculan setiap kata pada setiap dataset.

6. Backpropagation algoritma Cosine Similarity

Penggunaan algoritma Cosine Similarity dan Pembobotan TF-IDF untuk mengklasifikasikan teks pengaduan masyarakat, selanjutnya pengukuran perform tingkat prediksi (akurasi).

7. Analysis and Evaluation

Analisa dan evaluasi dari proses-proses di atas apakah klasifikasi hasil pengujian sesuai dengan klasifikasi teks atau kalimat pengaduan yang sebenarnya

Masing-masing bobot TF \& IDF dikalikan sehingga menjadi pembobotan TF.IDF. Bobot tiap term dimodelkan dalam vector space model hingga dilakukan perhitungan jarak kosinus antar sumbu bobot term menggunakan ukuran kemiripan cosine similarity [15]. Perhitungan cosine similarity memberikan hasil akhir nilai 0 hingga 1. Nilai 0 menunjukkan bahwa kalimat judul laporan tugas akhir tersebut tidak sesuai dengan query dan semakin mendekati 1 menunjukkan bahwa kalimat pengaduan tersebut sesuai dengan query [16]. Dari nilai kemiripan tersebut dokumen dapat kategorikan/diklasifikasikan mulai dari nilai tertinggi, yang paling sesuai hingga terendah, yang paling tidak sesuai [6]. 


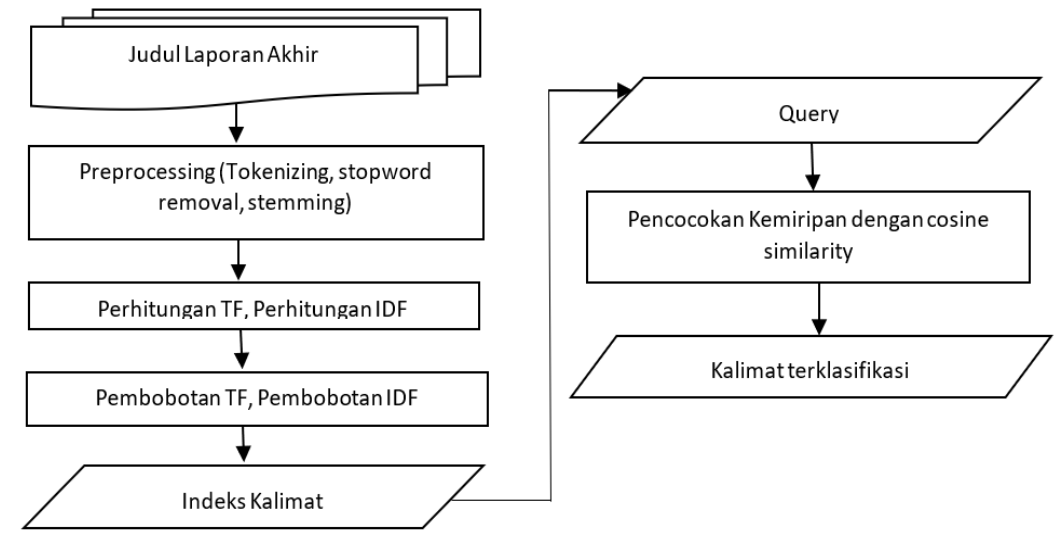

Gambar 2. Proses Alur Uji Coba

\subsection{Data Training}

Data yang digunakan dalam data basesebagai data pembanding untuk query uji latih, di mana data yang di ambil dari kumpulan judul-judul laporan tugas akhir mahasiswa yang sudah tamat sebelumnya yang telah menyelesaikan laporan tugas akhir sebelumnya dengan jumlah 50 judul yang di ambil dari mahasiswa yang sudah lulus sebelumnya. Kemudian akan di masukkan kedalam data base.

Tabel 1. Judul Laporan Tugas Akhir Yang Sudah Lulus

\begin{tabular}{|c|c|c|}
\hline No & $\begin{array}{c}\text { Nama } \\
\text { Mahasiswa }\end{array}$ & Judul Laporan Tugas Akhir \\
\hline 1 & $\begin{array}{l}\text { Desiana } \\
\text { Tumangger }\end{array}$ & $\begin{array}{l}\text { Pengaruh Pemberian Air Rebusan Seledri Pada Lansia Penderita Hipertensi Di } \\
\text { Puskesmas Kuta Tinggi Kecamatan Simpang Kanan Kabupaten Aceh Singkil Tahun } \\
2020\end{array}$ \\
\hline 2 & $\begin{array}{l}\text { Indriani Mutiara } \\
\text { Putri Saragih }\end{array}$ & $\begin{array}{l}\text { Pengaruh Aromaterapi Lavender Terhadap Intensitas Nyeri luka Perineum pada Ibu } \\
\text { Nifas Di Klinik Eka Sri Wahyuningsih Kec. Patumbak Kab. Deli Serdang Tahun } 2020\end{array}$ \\
\hline 3 & $\begin{array}{l}\text { Dede Irma } \\
\text { Suryani }\end{array}$ & $\begin{array}{l}\text { Pengaruh Pemberian Air Rebusan Daun Salam Terhadap Penurunan Kadar Asam Urat } \\
\text { Pada LansiaDi Dusun Sumber Sari Desa Torganda Kec. Torgamba Kab. Labuhanbatu } \\
\text { Selatan Tahun } 2020\end{array}$ \\
\hline 4 & $\begin{array}{l}\text { Meliska Br } \\
\text { Surbakti }\end{array}$ & $\begin{array}{l}\text { Perbandingan Berat Badan bayi Yang Di Berikan Asi Eksklusif \& Non Eksklusif Di } \\
\text { Wilayah Kerja Puskesmas Tiganderket Kec Tiganderket Kab Karo Tahun } 2020\end{array}$ \\
\hline 5 & $\begin{array}{l}\text { Aprilia } \\
\text { Hamdayani }\end{array}$ & $\begin{array}{l}\text { Efektifitas Pemberian Jus Jambu Biji Terhadap Peningkatan Hb Pada Mahasiswi } \\
\text { Tingkat I \& II Akademi Kebidanan Madina Husada Panyabungan Kec. Panyabungan } \\
\text { Tahun } 2020\end{array}$ \\
\hline 6 & $\begin{array}{l}\text { Sindy Clara } \\
\text { Dewi Br. } \\
\text { Sembiring }\end{array}$ & $\begin{array}{l}\text { Pengaruh Pijat Marmet Terhadap Kelancaran Pengeluaran Asi Pada Ibu Post Partum Di } \\
\text { Desa Simpang Pulo Rambung Kec. Bahorok Kab.Langkat Tahun } 2020\end{array}$ \\
\hline 7 & $\begin{array}{l}\text { Maulia Sari } \\
\text { Daulay }\end{array}$ & $\begin{array}{l}\text { Pengaruh Mengonsumsi Minuman Rebusan Kunyit Dalam Mengatasi Penurunan } \\
\text { Tingkat Nyeri Haid (Dysmenorrhea) Pada Remaja Putri Kelas VII \& VIII di MTS. Al- } \\
\text { Wasliyah Sei Berombang Tahun } 2020\end{array}$ \\
\hline 8 & Era Alpika & $\begin{array}{l}\text { Pengaruh Pemberian Jus Nanas \& Madu Terhadap Penurunan Tingkat Nyeri Menstruasi } \\
\text { (Dismenore)Pada Siswi Kelas VIII Di SMP N } 1 \text { Padang Tualang Kab. Langkat Tahun } \\
2020\end{array}$ \\
\hline 9 & $\begin{array}{l}\text { Shafira Wida } \\
\quad \text { Sari }\end{array}$ & $\begin{array}{l}\text { Hubungan Jenis Pekerjaan Ibu Dengan Pemberian Asi Eksklusif Di Klinik Bersalin } \\
\text { Suwarti KecematanDelitua Tahun } 2020\end{array}$ \\
\hline 10 & $\begin{array}{l}\text { Sri Endang } \\
\text { Marpaung }\end{array}$ & $\begin{array}{l}\text { Fator Yang Berhubungan Dengan Terjadinya Ketuban Pecah Dini (KPD) Di Rumah } \\
\text { Sakit Umum Sembiring Deli Tua Kecamatan Delitua Kabupaten Deli Serdang Tahun } \\
2020\end{array}$ \\
\hline 11 & Rahmayanti & $\begin{array}{l}\text { Hubungan Lingkar Lengan Atas (LILA) Ibu Hamil Dengan Taksiran Berat Janin Di } \\
\text { Wilayah Kerja Puskesmas Sampoiniet Kabupaten Aceh Utara Tahun } 2020\end{array}$ \\
\hline 12 & Ulfayanti & $\begin{array}{l}\text { Pengaruh Peyuluhan Tentang Personal Hygine Selama Menstruasi Terhadap } \\
\text { Pengetahuan \& Sikap Remaja Putir Di SMA Negeri } 1 \text { Peusangan Kecamatan Peusangan } \\
\text { Kab. Bireuen Tahun } 2020\end{array}$ \\
\hline 13 & Nolanda & $\begin{array}{l}\text { Efektifitas Daun Sirih Merah Terhadap Penyembuhan Luka Perineum Di Klinik Yusniar } \\
\text { Pangkalan Brandan Tahun } 2020\end{array}$ \\
\hline
\end{tabular}




\begin{tabular}{|c|c|c|}
\hline No & $\begin{array}{c}\text { Nama } \\
\text { Mahasiswa }\end{array}$ & Judul Laporan Tugas Akhir \\
\hline 14 & Cut Nanda & $\begin{array}{l}\text { Pengaruh Penyuluhan Tentang Personal Hygiene Terhadap Pengetahuan \& Sikap } \\
\text { Remaja Putri Yang Mengalami Flour Albus DI SMA Negeri } 1 \text { Peusangan } \\
\text { Kec.Peusangan Kab. Bireun Tahun } 2020\end{array}$ \\
\hline 15 & Sri Murni HSB & $\begin{array}{l}\text { Efektivitas Aroma Terapi la Vender Terhadap Jam Tidur Lansia Di Dusun IV Desa Suka } \\
\text { Makmur KecDelitua Kab. Deli Serdang Tahun } 2020\end{array}$ \\
\hline 16 & $\begin{array}{l}\text { Wahyu } \\
\text { Ramadhani Br } \\
\text { Tarigan }\end{array}$ & $\begin{array}{l}\text { Pengaruh Yoga Terhadap Tingkat Kecemasan Pada Ibu Hamil Primigravida Trimester } \\
\text { III Di Bidan Praktek Mandiri Pera Kecamatan Medan Tuntungan Tahun } 2020\end{array}$ \\
\hline 17 & $\begin{array}{l}\text { Mawaddah } \\
\text { Azriyanti } \\
\text { Ritonga }\end{array}$ & $\begin{array}{l}\text { Hubungan Pengetahuan Dengan Sikap Pada Konsumsi tablet Fe Di Posyandu Taman } \\
\text { Sari Tahun } 2020\end{array}$ \\
\hline 18 & $\begin{array}{l}\text { Sintia Elisabet } \\
\text { Hutabarat }\end{array}$ & $\begin{array}{l}\text { Pengaruh Konsumsi Daun Ubi Jalar (Ipomoea Batatas) Terhadap Perubahan kadar } \\
\text { Hemoglobin Pada Ibuhamil Klinik Ridho Kec. Medan Perjuangan Kota Medan Tahun } \\
2020\end{array}$ \\
\hline 19 & $\begin{array}{l}\text { Gita Danaya Br. } \\
\text { Tampubolon }\end{array}$ & $\begin{array}{l}\text { Hubungan Belly Dance Dengan kelancaran Proses Persalinan pada Ibu Hamil Di Klinik } \\
\text { Desmawati Kec.Pancur Batu Kab. Deli Serdang }\end{array}$ \\
\hline 20 & $\begin{array}{l}\text { novrywantuti } \\
\quad \text { Zebua }\end{array}$ & $\begin{array}{l}\text { Efektivitas Konsumsi Putih Telur Rebus Terhadap Proses Penyembuhan Luka Prineum } \\
\text { Pada Ibu PostpartumDi Klinik Linez JL. Prof Dr Sutomo No } 3 \text { Mudik Kec. Gunungsitoli } \\
\text { Tahun } 2020\end{array}$ \\
\hline 21 & $\begin{array}{l}\text { Deviana } \\
\text { Harahap }\end{array}$ & $\begin{array}{l}\text { Pengaruh Penatalaksanaan Asuhan Sayang Ibu Terhadap Kecemasan Ibu Selama Proses } \\
\text { Persalinan Di BPMNurliani Desa Pudun AE Kota Padangsidumpuan Tahun } 2020\end{array}$ \\
\hline 22 & $\begin{array}{l}\text { Vingky } \\
\text { Aderamona } \\
\text { Purba }\end{array}$ & $\begin{array}{l}\text { Perbandingan Kelancaran Produksi Asi Pada Ibu Nifas yang Konsumsi Jantung Pisang } \\
\text { Kepok \& Jantung Pisang Batu Di BPM Anita Situmorang Kota Tebing Tinggi Tahun } \\
2020\end{array}$ \\
\hline 23 & $\begin{array}{l}\text { Ernawati Saritua } \\
\text { Tarihoran }\end{array}$ & $\begin{array}{l}\text { Perbandingan Pijat Oksitosin Dengan Inisiasi Menyusu Dini Terhadap Kelancaran } \\
\text { Produksi Asi Di Klinik Bersalin Bidan Wilayah kerja Puskesmas Bosar Maligas Tahun } \\
2020\end{array}$ \\
\hline 24 & $\begin{array}{l}\text { Witty Dwika } \\
\text { sari Ndruru }\end{array}$ & $\begin{array}{l}\text { Pegnaruh Mobilisasi Dini Terhadap Penurunan Tinggi Fundus Uteri Pada Ibu Nifas Di } \\
\text { Rsu Sembiring Tahun } 2020\end{array}$ \\
\hline 25 & $\begin{array}{l}\text { Dwi Sri } \\
\text { Mulianingsih }\end{array}$ & $\begin{array}{l}\text { Pengaruh kualitas Sumber Daya Manusia Terhadap Kunjungan Antenatalcare (ANC) } \\
\text { Di Puskesmas Karang Anyar Kec. Beringin Kab Deli Serdang. Tahun } 2020\end{array}$ \\
\hline 26 & Heni Pratiwi & $\begin{array}{l}\text { Pengaruh Kompres Daun Kubis (Brassica Oleracea Var Capital) Terhadap Pengurangan } \\
\text { Pembengkakan Payudara Pada Ibu Postpartum Di Kel. Bela Rakyat Kec. Kuala Kab } \\
\text { Langkat Tahun } 2020\end{array}$ \\
\hline 27 & Angga Husada & $\begin{array}{l}\text { Pengaruh Penundaan pemotongan tali Pusat Terhadap Lama Lahir Plasenta Di Praktik } \\
\text { Mandiri Bidan Mariani Kecamatan Syamtalira Bayu Kab. Aceh Utara Tahun } 2020\end{array}$ \\
\hline 28 & Betty Sembiring & $\begin{array}{l}\text { faktor-Faktor yang Mempengaruhi Penatalaksanaan 14T Pada Antenatal Care Di } \\
\text { Puskesmas Delitua Kec.Delitua Kab. Deli Serdang Tahun } 2020\end{array}$ \\
\hline 29 & Wiwanti Gea & $\begin{array}{l}\text { Pengaruh Endorphin Massage Terhadap Intensitas Nyeri Kala I Fase Aktif Pada Ibu } \\
\text { Bersalin Primigra Vida DIKlinik Hili Kec. Lotu Kab. Nias Utara Tahun } 2020\end{array}$ \\
\hline 30 & $\begin{array}{l}\text { Khamalia } \\
\text { Syafaisyah }\end{array}$ & $\begin{array}{l}\text { Faktor-Faktor Yang Mempengaruhi Kejadian Post partum Blues Pada Ibu Nifas Di Rsu } \\
\text { Madani Medan Tahun } 2020\end{array}$ \\
\hline 31 & $\begin{array}{l}\text { Juni Anggrenita } \\
\text { Siregar }\end{array}$ & $\begin{array}{l}\text { Pengaruh Pijat Oksitoksin Terhadap pengeluaran Kolostrum Pada Ibu Nifas Di BPM } \\
\text { Aida Nospita Jalan Veteran Pasar VII Desa manunggal Kec. Labuhan Delli Tahun } 2020\end{array}$ \\
\hline 32 & Hermawati & $\begin{array}{l}\text { Pengaruh Pemberian Buah Pepaya (Carica papaya) Terhadap Peningkatan Produksi Asi } \\
\text { Pada Ibu Nifas Di Desa Huta I Boluk Kecamatan Bosar Maligas Kab. Simalungun } \\
\text { Tahun } 2020\end{array}$ \\
\hline 33 & Uli Sasrifa & $\begin{array}{l}\text { Pengaruh Mengkonsumsi Pisang Ambon Terhadap Peningkatan Kadarhemoglobin Pada } \\
\text { Ibu Hamil Di KlinikSuwarti Kec. Deli Tua Kab. Deli Serdang Tahun } 2020\end{array}$ \\
\hline 34 & $\begin{array}{l}\text { Juwita Fitrah } \\
\text { Telaumbanua }\end{array}$ & $\begin{array}{l}\text { Pengaruh Pemberian Air Rebsuan Daun jambu Biji Terhadap Penyembuhan Diare Pada } \\
\text { Balita Di PuskesmasBiru-Biru kec.Biru-biru kab. Deli Serdang Tahun } 2020\end{array}$ \\
\hline 35 & $\begin{array}{l}\text { Siti Rahma } \\
\text { Hasibuan }\end{array}$ & $\begin{array}{l}\text { Efektivitas Daun Katuk (Sauropus Androgynus) Terhadap Kecukupan Asi Pada Ibu } \\
\text { Menyusu Di KlinikPratama Grace Kec. Delitua Kab. Deli Serdang Tahun } 2020\end{array}$ \\
\hline 36 & $\begin{array}{c}\text { Afnan Sri } \\
\text { Wulan Gea }\end{array}$ & $\begin{array}{l}\text { Pengaruh Massage Endorpin Terhadap Tingkat Kecemasan ibu Bersalin Primigravida } \\
\text { Kala I Di Klinik Bersalinhili Kec. Lotu Kab. Nias Utara Tahun } 2020\end{array}$ \\
\hline
\end{tabular}




\begin{tabular}{|c|c|c|}
\hline No & $\begin{array}{c}\text { Nama } \\
\text { Mahasiswa }\end{array}$ & Judul Laporan Tugas Akhir \\
\hline 37 & $\begin{array}{l}\text { Miftania } \\
\text { Rerimna } \mathrm{Br} \\
\text { Sembiring }\end{array}$ & $\begin{array}{l}\text { Pengaruh Pemeberian Minuman Kunyit Asam jawa Terhadap Penurunan Intensitas } \\
\text { Nyeri Menstruasi Pada Remaja Putri Di Desa namu Ukur Utara Kec. Sei Bingai Kab. } \\
\text { Langkat }\end{array}$ \\
\hline 38 & Dewi Wahyuni & $\begin{array}{l}\text { Pengaruh Konsumsi Jus Kacang Hijau (Phaseolus Radiatus) Terhadap Hemoglobin Ibu } \\
\text { Hamil Anemia Di Puskesmas TJ Pasir Kec. Kualuh Selatan Kab. Labuhan batu Utara } \\
\text { Tahun } 2020\end{array}$ \\
\hline 39 & $\begin{array}{l}\text { Endaha Richa } \\
\text { Putri Ginting }\end{array}$ & $\begin{array}{l}\text { Hubungan Pengetahuan \& Sikap Ibu Tentang Status Gizi Ibu Hamil Di puskesmas } \\
\text { Rantau Parapat kab. Labuhan batu } 2020\end{array}$ \\
\hline 40 & $\begin{array}{l}\text { Septi Dayanti } \\
\text { Ritonga }\end{array}$ & $\begin{array}{l}\text { Pengaruh Minum Jamu (Ramuan Daun Katuk, Kunyit, Lempuyangan, Asam Jawa) } \\
\text { Terhadap Peningkatan Produksi Pada Ibu Nifas Di Klinik Suwarti Kec.Delitua Kab. } \\
\text { Deli Serdang Tahun } 2020\end{array}$ \\
\hline 41 & $\begin{array}{l}\text { Naptalia } \\
\text { Adresina } \\
\text { Tarigan }\end{array}$ & $\begin{array}{l}\text { Hubungan Pengetahuan Ibu Tentang Status Gizi Dengan Kejadian Gizi Buruk pada } \\
\text { Balita DI Desa Bakaran batu Kab. Deli Serdang tahun } 2020\end{array}$ \\
\hline 42 & Sri Wahyuni & $\begin{array}{l}\text { Efejtifitas Penggunaan Asi Pada Perawatan luka Perineum Dengan Lama Waktu } \\
\text { Penyembuhan Luka Perineumpada Ibu Nifas Di Klinik Ridho Desa Aek Korsik Kec. } \\
\text { Aek Kuo Kab. Labuhan Batu Utara Tahun } 2020\end{array}$ \\
\hline 43 & $\begin{array}{c}\text { Noni } \\
\text { Rahmadani }\end{array}$ & $\begin{array}{l}\text { Hubungan Pengetahuan Ibu Nifas Tentang Perawatan Payudara Dengan Minat Ibu } \\
\text { Untuk Menyusui DiPuskesmas Merbau Kecamatan Merbau Tahun } 2020\end{array}$ \\
\hline 44 & Mona Lianda & $\begin{array}{l}\text { Efektifitas Kombinasi Massage Effleurage \& Aromaterapi Lavender Terhadap } \\
\text { Pengurangan Nyeri PersalinanKala Fase Aktif Di PMB Efayan Kec. Syamtalira Bayu } \\
\text { Kab. Aceh Utara Tahun } 2020\end{array}$ \\
\hline 45 & Widia Royanda & $\begin{array}{l}\text { Pengaruh Seduhan Zingiber Offcinale (Jahe) Terhadap Penurunan Emesis Gravidarum } \\
\text { Pada Ibu Hamil Trimester I Di Klinik Pratama Sehati Husada Kec. Biru-biru Kab. Deli } \\
\text { Serdang Tahun } 2020\end{array}$ \\
\hline 46 & $\begin{array}{l}\text { Eka Suci } \\
\text { Rahayu Rambe }\end{array}$ & $\begin{array}{l}\text { Faktor Yang Mempengaruhi Anemia Pada Ibu Hamil Di Puskesmas Balai Jaya Tahun } \\
2020\end{array}$ \\
\hline 47 & Eni Eviana & $\begin{array}{l}\text { Hubungan Tindakan Personal Hygine Ibu Dengan Kejadian Diare Pada Balita Di BPM } \\
\text { Pera Medan Tuntungan Tahun } 2020\end{array}$ \\
\hline 48 & Eka Rahmayanti & $\begin{array}{l}\text { Pengaruh Pijat Bayi Terhadap Kualitas Tidur Bayi Usia 1-6 Bulan Di BPM Pera Kec. } \\
\text { Medan Tuntungan Tahun } 2020\end{array}$ \\
\hline 49 & Fitraini Sitorus & $\begin{array}{l}\text { Pengaruh Konsumsi Jus Bayam Merah Terhadap Peningkat Kadar HB Pada Ibu Hamil } \\
\text { Di Puskesmas PoriahaKec. Tapanuli Tengah Tahun } 2020\end{array}$ \\
\hline 50 & $\begin{array}{l}\text { Cut Desy } \\
\text { Asrianti }\end{array}$ & $\begin{array}{l}\text { Hubungan Pengetahuan \& Sikap Bidan Praktik Mandiri Dengan Kepatuhan } \\
\text { Menjalankan Standar Pelayanan Antenatal Care Di Wilayah Kerja Puskesmas Nibong } \\
\text { Kab. Aceh Utara Tahun } 2020\end{array}$ \\
\hline
\end{tabular}

\subsection{Data Latih}

Daftar judul laporan tugas akhir yang bersal dari mahasiswa aktif yang sedang dalam proses pengajuan judul ke program studi dengan jumlah 21 judul laporan tugas akhir. judul ini akan di uji latih terhadap data training.

Tabel 2. Judul Laporan Tugas Akhir Mahasiswa Aktif

\begin{tabular}{|c|c|c|}
\hline NO & $\begin{array}{c}\text { Nama } \\
\text { Mahasiswa }\end{array}$ & Judul Laporan Tugas Akhir \\
\hline 1 & $\begin{array}{l}\text { AJENG } \\
\text { WIDAYANTI }\end{array}$ & 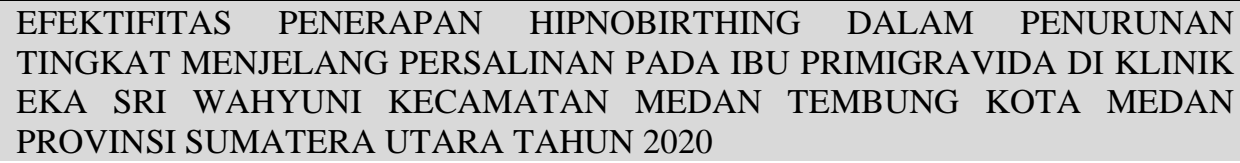 \\
\hline 2 & $\begin{array}{l}\text { ANELLA } \\
\text { FADILLAH }\end{array}$ & $\begin{array}{l}\text { PENGARUH KONDISI DIABETES PADA IBU HAMIL TERHADAP KEJADIAN } \\
\text { MAKROSOMIA PADA BAYI BARU LAHIR DI RSU SEMBIRING KECAMATAN } \\
\text { DELI TUA KABUPATEN DELI SERDANG PROVINSI SUMATERA UTARA } \\
\text { TAHUN } 2020\end{array}$ \\
\hline 3 & $\begin{array}{l}\text { ANISA } \\
\text { TRIHAFSARI }\end{array}$ & $\begin{array}{l}\text { FAKTOR-FAKTOR YANG MEMPENGARUHI KUNJUNGAN IBU DALAM } \\
\text { PEMANFAATAN POSYANDU BALITA DI PUSKESMAS DELITUA } \\
\text { KABUPATEN DELI SERDANG PROV. SUMATERA UTARA TAHUN } 2020\end{array}$ \\
\hline
\end{tabular}




\begin{tabular}{|c|c|c|}
\hline NO & $\begin{array}{c}\text { Nama } \\
\text { Mahasiswa }\end{array}$ & \\
\hline & NISYA & RIAN MADU \\
\hline 4 & & ERI MENSTRUASI PADA WANITA REMAJA DI $\mathrm{K}$ \\
\hline & & BUPATEN DELI SERDANG PROVINSI S \\
\hline 5 & $\begin{array}{l}\text { INISA } \\
\text { VRI } \\
\text { SUMA } \\
\text { JTASUHUT }\end{array}$ & $\begin{array}{l}\text { PENGARUH KOMSUMSI JUS BUAH SEMANGKA TERHADAP PENURUNAN } \\
\text { TEKANAN DARAH TINGGI PADA LANSIA DI PUSKESMAS DELI TUA } \\
\text { KEC.DELI TUA KAB.DELI SERDANG PROVINSI SUMATERA UTARA TAHUN } \\
2020\end{array}$ \\
\hline 6 & $\begin{array}{l}\text { APRIANI } \\
\text { BARUS }\end{array}$ & $\begin{array}{l}\text { PENGARUH PEMBERIAN SUPLEMEN ZAT BESI TERHADAP PENINGKATAN } \\
\text { KADAR HEMOGLOBIN PADA REMAJA PUTRI SETELAH MENSTRUASI DI } \\
\text { KLINIK SULASTRI KEC.BIRU-BIRU KAB.DELI } \\
\text { SUMATERA UTARA TAHUN } 2020\end{array}$ \\
\hline 7 & $\begin{array}{l}\text { AYU RIZKYA } \\
\text { PUTRI }\end{array}$ & $\begin{array}{l}\text { HUBUNGAN IBU HAMIL PEROKOK PASIF DENGAN KEJADIAN BBLR DI RSU } \\
\text { SEMBIRING KECAMATAN DELI TUA KABUPATEN DELI SERDANG } \\
\text { PROVINSI SUMATERA UTARA TAHUN } 2020\end{array}$ \\
\hline 8 & $\begin{array}{l}\text { AYU SRI } \\
\text { NINGSIH }\end{array}$ & $\begin{array}{l}\text { PENGARUH ANEMIA DAN KEKURANGAN ENERGI KRONIS PADA IBU } \\
\text { HAMIL DENGAN KEJADIAN BBLR DI KLINIK NINING PELAWATI } \\
\text { KEC.LUBUK PAKAM KAB.DELI SERDANG PROV. SUMATERA UTARA } \\
\text { TAHUN } 2020\end{array}$ \\
\hline 9 & $\begin{array}{l}\text { JDY } \\
\text { INDA } \\
\text { NDIRA }\end{array}$ & $\begin{array}{l}\text { HUBUNGAN TEKNIK PIJAT EFFLAURAGE DENGAN PENURUNAN NYERI } \\
\text { PERSALINAN KALA I DI KLINIK BERSALIN NINING PELAWATI LUBUK } \\
\text { PAKAM KABUPATEN DELI SERDANG PROVINSI SUMATERA UTARA TAHUN } \\
2020\end{array}$ \\
\hline 10 & $\begin{array}{l}\text { DEVI } \\
\text { WULANDARI }\end{array}$ & $\begin{array}{l}\text { ARUH RANGSANGAN PUTTING SUSU TERHADAP PENINGKATAN } \\
\text { RAKSI UTERUS PADA IBU INPARTU KALA II DI KLINIK TANJUNG } \\
\text { MATAN DELI TUA KABUPATEN DELI SERDANG PROVINSI } \\
\text { TERA UTARA TAHUN } 2020\end{array}$ \\
\hline 11 & $\begin{array}{l}\text { DEWI } \\
\text { AZURA }\end{array}$ & $\begin{array}{l}\text { IAN JUS BUAH BIT TERHADAP KENAIKAN KADAR } \\
\text { IBU HAMIL DI KLINIK NINING PELAWATI KEC.LUBUK } \\
\text { RDANG PROVINSI SUMATERA UTARA TAHUN } 2020\end{array}$ \\
\hline 12 & $\begin{array}{l}\text { WI } \\
\text { RNI }\end{array}$ & $\begin{array}{l}\text { AHUAN SUAMI TERHADAP TINGKAT KECEMASAN } \\
\text { AN SEKSUAL PADA IBU HAMIL DI KLINIK CITRA } \\
\text { ATAN DELI TUA KABUPATEN DELI } \\
\text { UTARA TAHUN } 2020\end{array}$ \\
\hline 13 & $\begin{array}{l}\text { DIAN } \\
\text { PRATIWI }\end{array}$ & $\begin{array}{l}\text { BADAN LAHIR RENDAH DENGAN } \\
\text { ESMAS NAMORAMBE KABUPATEN } \\
\text { JTARA TAHUN } 2020\end{array}$ \\
\hline 14 & $\begin{array}{l}\text { DWIPA AGIL } \\
\text { ROUZA }\end{array}$ & $\begin{array}{l}\text { G SEPATU TERHADAP PENURUNAN } \\
\text { CAMATAN NAMORAMBE KABUPATEN } \\
\text { RA UTARA TAHUN } 2020\end{array}$ \\
\hline 15 & DITT & $\begin{array}{l}\text { BUNGAN KOMUNIKASI TERAUPEUTIK DENGAN INTENSITAS NYERI } \\
\text { DA PERSALINAN PRIMIGRAVIDA INPARTU KALA I DI KLINIK BERSALIN } \\
\text { NING PELAWATI LUBUK PAKAM KABUPATEN DELI SERDANG PROVINSI } \\
\text { MATERA UTARA TAHUN } 2020\end{array}$ \\
\hline 16 & $\begin{array}{l}\text { Elfrida } \\
\text { Casanov } \\
\text { Barasa }\end{array}$ & \begin{tabular}{llllll} 
PENGARUH SENAM ABDOMINAL STRECHING & \multicolumn{2}{c}{ EXERCISE } & TERHADAP \\
PENURUNAN DISMINORHEA PADA & REMAJA & PUTRI DI & SMA RK \\
KECAMATAN DELI TUA KABUPATEN & DELI & SERDANG & PROVINSI \\
SUMATERA UTARA TAHUN 2020 & & &
\end{tabular} \\
\hline 17 & A & PEMBERIAN INISIASI MENYUSUI DINI TERHADAP KE \\
\hline 18 & $\begin{array}{l}\text { RIA } \\
\text { ITA }\end{array}$ & $\begin{array}{l}\text { FAKTOR-FAKTOR YANG MEMPENGARUHI PEMBERIAN KOLOSTRUM PADA } \\
\text { BAYI BARU LAHIR DI KLINIK MADINA KECAMATAN MEDAN TEMBUNG } \\
\text { KOTA MEDAN PROVINSI SUMATERA UTARA TAHUN } 2020\end{array}$ \\
\hline 19 & $\begin{array}{l}\text { AULIA } \\
\text { LAH }\end{array}$ & $\begin{array}{l}\text { JH PEMBERIAN RENDAMAN RUMPUT FATIMAH (ANASTATICA } \\
\text { UNTICA) TERHADAP KONTRAKSI UTERUS PADA IBU BERSALIN } \\
\text { K SUMIARIANI KEC.MEDAN JOHOR KAB.DELI SERDANG PROVINSI } \\
\text { RA UTARA TAHUN } 2020\end{array}$ \\
\hline
\end{tabular}



DOI 10.30865/mib.v5i2.2935

\begin{tabular}{clllll}
\hline NO & \multicolumn{2}{c}{$\begin{array}{c}\text { Nama } \\
\text { Mahasiswa }\end{array}$} & & \multicolumn{3}{c}{ Judul Laporan Tugas Akhir } \\
& FITRI & HUBUNGAN RIWAYAT HIPERTENSI DENGAN KEJADIAN PRE EKLAMPSI \\
20 & AMELIA & PADA IBU BERSALIN DI RSU.SEMBIRING KEC.DELI & TUA & KAB.DELI \\
& & SERDANG PROVINSI SUMATERA UTARA TAHUN 2020 & \\
& & PENGARUH PEMBERIAN SUSU KEDELAI TERHADAP & PENINGKATAN \\
21 & FITRIANI & PRODUKSI ASI PADA IBU NIFAS DI KLINIK KASIH IBU KECAMATAN DELI \\
& RAHAYU & TUA KABUPATEN DELI SERDANG PROVINSI SUMATERA UTARA TAHUN \\
& & 2020 \\
\hline
\end{tabular}

\subsection{Uji Coba Pada System}

Tools untuk melakukan testing menggunakan aplikasi berbasis web dengan Bahasa pemograman PHP dan menggi menggunakan xampp-MYSQL. Pada tools ini hanya memiliki 1 level user yaitu administrator. Pada halaman administrator ini lah dilakukan update data training, perhitungan Cosine Similarity dan Pembobotan TF-IDF. Berikut tampilan sistem:

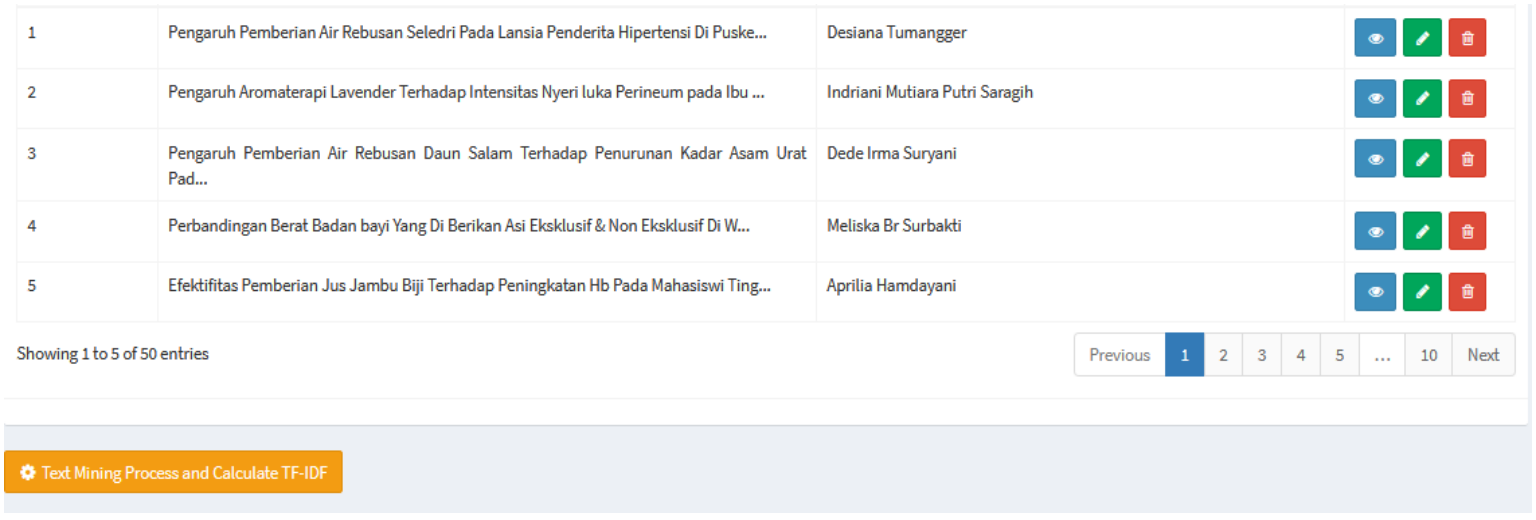

Gambar 3. Halaman Daftar Training

Halaman data training merupakan daftar halaman kalimat laporan tugas akhir yang telah di input kedalam sistem dan telah di di klasifikasikan sesuai dengan nama alumni pemilik judul laporan tugas akhirnya. Data ini akan akan di proses pada case folding menggunakan pembobotan TF-IDF sehingga menghasilkan term pada setiap kalimat judul laporan tugas akhir.

PENGARUH PEMBERIAN SUSU KEDELAI TERHADAP PENINGKATAN PRODUKSSI ASI PADA IBU NIFAS DI KLINIK KASIH IBU KECAMATAN DELI TUA KABUPATEN DELI SERDANG PROVINSS SUMATERA UTARA TAHUN 2020

\section{Gambar 4. Halaman Uji Latih}

Tampilan halaman input/masukan untuk melakukan data latih terhadap data training yang ada, tampilan ini hanya menampung satu kalimat judul tugas akhir sehingga untuk melakukan uji coba di lakukan satu persatu terhadap judul laporan tugas akhir. 


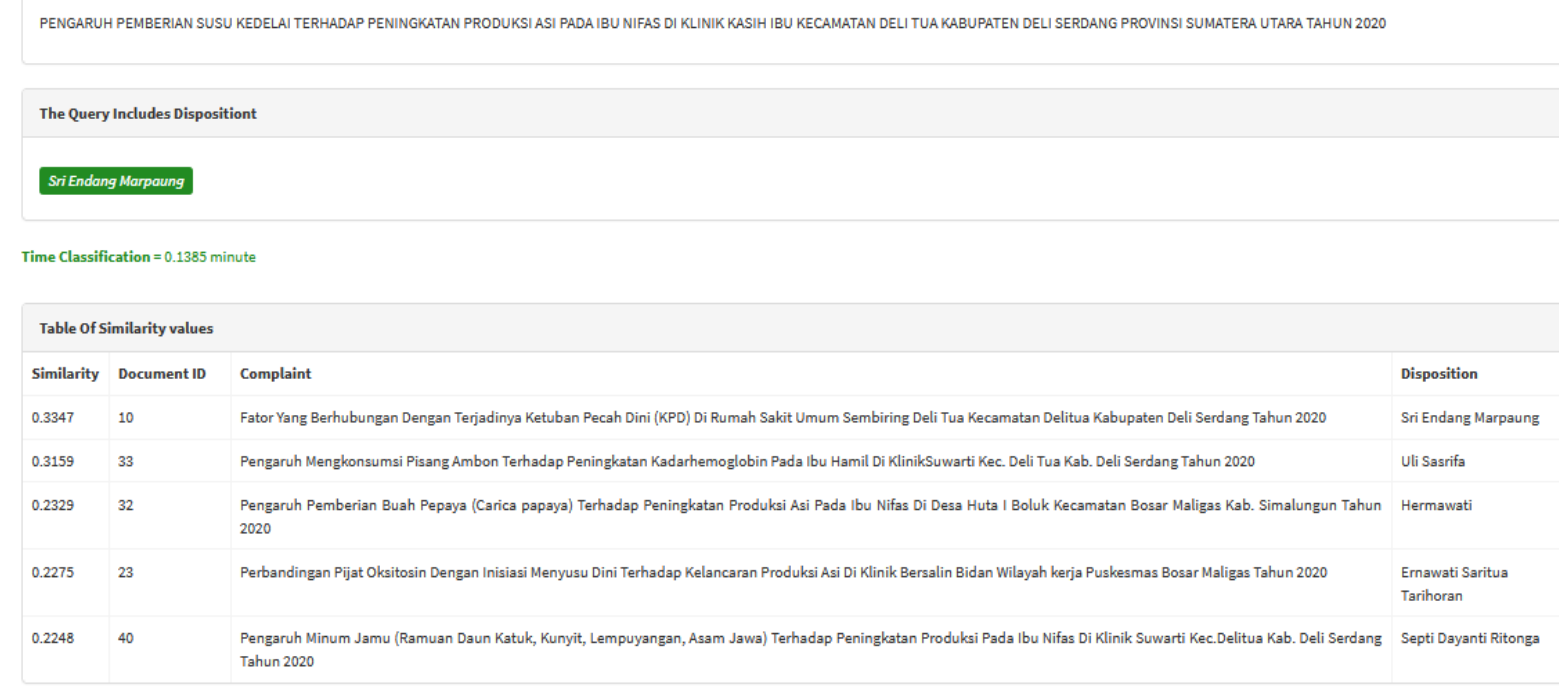

Gambar 5. Halaman Hasil Proses Uji Latih

Tampilan halaman hasil dari uji latih yang di lakukan terhadap data training, pada gambar 5 terlihat kemiripan judul laporan tugas akhir yang baru terhadap judul tugas akhir yang telah ada pada data base sebelumnya, maka untuk memutuskan judul laporan akhir ini layak ataw tidak layak di lihat dari persen kemiripan dengan judul laporan akhir alumni sebelumnya.

\subsection{Hasil Analisa Moteode Metode Cosine Similarity dan Pembobotan TF-IDF}

Hasil analisis dilakukan melalui tahapan proses pada Gambar 1, untuk kalkulasi data menggunakan rumus cosine similarity dengan pembobotan kata dengan rumus berikut;

$$
\begin{aligned}
& \text { similarity }=\cos (\varnothing)=\frac{A . B}{\|A\| B \|} \frac{\sum_{i=1}^{n} A i x B i}{\sqrt{\sum_{i-1}^{n}(A i) 2} \times \sum_{i-1}^{n}(B i) 2} \\
& T F-I D F(w, d)=\frac{\mathrm{TD}-\mathrm{IDF}(\mathrm{w}, \mathrm{d})}{\sqrt{\sum_{w=1}^{n} T F-I D F(w, d) 2}}
\end{aligned}
$$

Berikut hasil uji coba data latih terhadap data dtraining dapat dilihat pada Table 3 dengan jumlah data training 50 kalimat judul laporan tugas akhir dan 21 data latih.

\begin{tabular}{|c|c|c|c|c|c|c|c|c|c|c|c|c|c|c|c|}
\hline No & $\begin{array}{c}\text { ID } \\
\text { Data } \\
\text { Latih }\end{array}$ & D2 & D9 & D10 & D23 & D28 & D29 & D30 & D33 & D34 & D36 & D37 & D38 & D41 & D46 \\
\hline 1 & Q1 & & & & & & 0.54 & & & & & & & & \\
\hline 2 & Q2 & 0.30 & & & & & & & & & & & & & \\
\hline 3 & Q3 & & & & & 0.50 & & & & & & & & & \\
\hline 4 & Q4 & & & & & & & & & & & 0.34 & & & \\
\hline 5 & Q5 & & & & & & & & 0.38 & & & & & & \\
\hline 6 & Q6 & & & & & & & & & 0.52 & & & & & \\
\hline 7 & Q7 & & & 0.45 & & & & & & & & & & & \\
\hline 8 & Q8 & & & & & & & & & & & & & & 0.33 \\
\hline 9 & Q9 & & & & & & 0.25 & & & & & & & & \\
\hline 10 & Q10 & & & 0.37 & & & & & & & & & & & \\
\hline 11 & Q11 & & & & & & & & & & & & 0.24 & & \\
\hline 12 & Q12 & & & 0.39 & & & & & & & & & & & \\
\hline 13 & Q13 & & & & & & & & & & & & & 0.50 & \\
\hline 14 & Q14 & & & 0.28 & & & & & & & & & & & \\
\hline 15 & Q15 & & & & & & & & & & 0.36 & & & & \\
\hline 16 & Q16 & & & 0.34 & & & & & & & & & & & \\
\hline 17 & Q17 & & & & 0.26 & & & & & & & & & & \\
\hline
\end{tabular}

Tabel 3. Hasil pembobotan dan similarity 


\begin{tabular}{|c|c|c|c|c|c|c|c|c|c|c|c|c|c|c|c|}
\hline No & $\begin{array}{c}\text { ID } \\
\text { Data } \\
\text { Latih }\end{array}$ & D2 & D9 & D10 & D23 & D28 & D29 & D30 & D33 & D34 & D36 & D37 & D38 & D41 & D46 \\
\hline 18 & Q18 & & & & & & & 0.36 & & & & & & & \\
\hline 19 & Q19 & & 0.25 & & & & & & & & & & & & \\
\hline 20 & Q20 & & & 0.32 & & & & & & & & & & & \\
\hline 21 & Q21 & & & 0.33 & & & & & & & & & & & \\
\hline
\end{tabular}

\subsection{Hasil Evaluasi Data Latih Terhadap Data Training}

Berikut hasil uji data latih yang dilakukan testing uji dengan satu-persatu, dengan jumlah data 21 kalimat judul laporan akhir.

Tabel 4. Hasil Uji Latih

\begin{tabular}{|c|c|c|c|c|c|}
\hline No & Judul Laporan Akhir Pada Data Latih & $\begin{array}{l}\text { Persentasi } \\
\text { Kemiripan }\end{array}$ & $\begin{array}{c}\text { Hasil } \\
\text { Similarity }\end{array}$ & Waktu & $\begin{array}{l}\text { Nama } \\
\text { Pemilik Judul } \\
\text { Laporan } \\
\text { Akhir Pada } \\
\text { Data Training }\end{array}$ \\
\hline 1 & $\begin{array}{lcr}\text { PENGARUH } & \text { MASSASE } & \text { PUNGGUNG } \\
\text { TERHADAP } & \text { PENURUNAN } & \text { INTENSITAS } \\
\text { NYERI PERSALINAN KALA I FASE AKTIF DI } \\
\text { KLINIK BETARIA HUTABARAT KEC. LUBUK } \\
\text { PAKAM KAB.DELI SERDANG } & \text { PROVINSI } \\
\text { SUMATERA UTARA TAHUN 2020 } & \end{array}$ & $54.16 \%$ & $\begin{array}{c}\text { Tidak } \\
\text { Memenuhi }\end{array}$ & 0.1124 & Wiwanti Gea \\
\hline 2 & 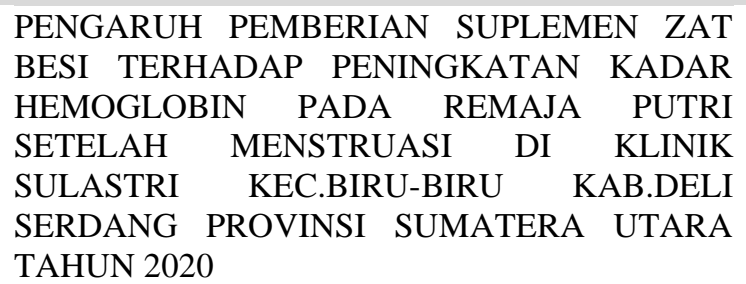 & $51.95 \%$ & $\begin{array}{c}\text { Tidak } \\
\text { Memenuhi }\end{array}$ & 0.1138 & $\begin{array}{l}\text { Juwita Fitrah } \\
\text { Telaumbanua }\end{array}$ \\
\hline 3 & $\begin{array}{l}\text { HUBUNGAN STATUS GIZI DAN BERAT } \\
\text { BADAN LAHIR RENDAH DENGAN KEJADIAN } \\
\text { ISPA PADA BALITA DI PUSKESMAS } \\
\text { NAMORAMBE KABUPATEN DELI SERDANG } \\
\text { PROVINSI SUMATERA UTARA TAHUN } 2020\end{array}$ & $50.37 \%$ & $\begin{array}{c}\text { Tidak } \\
\text { Memenuhi }\end{array}$ & 0.1267 & $\begin{array}{l}\text { Naptalia } \\
\text { Adresina } \\
\text { Tarigan }\end{array}$ \\
\hline 4 & $\begin{array}{l}\text { FAKTOR-FAKTOR YANG MEMPENGARUHI } \\
\text { KUNJUNGAN IBU DALAM PEMANFAATAN } \\
\text { POSYANDU BALITA DI PUSKESMAS } \\
\text { DELITUA KABUPATEN DELI SERDANG } \\
\text { PROV. SUMATERA UTARA TAHUN } 2020\end{array}$ & $49.85 \%$ & $\begin{array}{c}\text { Tidak } \\
\text { Memenuhi }\end{array}$ & 0.1269 & $\begin{array}{c}\text { Betty } \\
\text { Sembiring }\end{array}$ \\
\hline 5 & $\begin{array}{llrr}\text { HUBUNGAN IBU HAMIL PEROKOK } & \text { PASIF } \\
\text { DENGAN KEJADIAN BBLR } & \text { DI } & \text { RSU } \\
\text { SEMBIRING } & \text { KECAMATAN DELI } & \text { TUA } \\
\text { KABUPATEN } & \text { DELI SERDANG } & \text { PROVINSI } \\
\text { SUMATERA UTARA TAHUN 2020 } & & \end{array}$ & $45.36 \%$ & $\begin{array}{c}\text { Tidak } \\
\text { Memenuhi }\end{array}$ & 0.0975 & $\begin{array}{l}\text { Sri Endang } \\
\text { Marpaung }\end{array}$ \\
\hline 6 & $\begin{array}{l}\text { HUBUNGAN PENGETAHUAN SUAMI } \\
\text { TERHADAP TINGKAT KECEMASAN DALAM } \\
\text { BERHUBUNGAN SEKSUAL PADA IBU HAMIL } \\
\text { DI KLINIK CITRA MARENDAL KECAMATAN } \\
\text { DELI TUA KABUPATEN DELI SERDANG } \\
\text { PROVINSI SUMATERA UTARA TAHUN } 2020\end{array}$ & $38.74 \%$ & $\begin{array}{c}\text { Tidak } \\
\text { Memenuhi }\end{array}$ & 0.1509 & $\begin{array}{l}\text { Sri Endang } \\
\text { Marpaung }\end{array}$ \\
\hline 7 & $\begin{array}{lll}\text { PENGARUH } & \text { KOMSUMSI JUS BUAH } \\
\text { SEMANGKA TERHADAP } & \text { PENURUNAN } \\
\text { TEKANAN DARAH TINGGI PADA LANSIA DI } \\
\text { PUSKESMAS DELI TUA KEC.DELI TUA } \\
\text { KAB.DELI SERDANG PROVINSI SUMATERA } \\
\text { UTARA TAHUN } 2020\end{array}$ & $37.83 \%$ & $\begin{array}{c}\text { Tidak } \\
\text { Memenuhi }\end{array}$ & 0.1314 & Uli Sasrifa \\
\hline 8 & $\begin{array}{l}\text { PENGARUH RANGSANGAN PUTTING SUSU } \\
\text { TERHADAP PENINGKATAN KONTRAKSI } \\
\text { UTERUS PADA IBU INPARTU KALA II DI }\end{array}$ & $37.31 \%$ & $\begin{array}{c}\text { Tidak } \\
\text { Memenuhi }\end{array}$ & 0.1084 & $\begin{array}{l}\text { Sri Endang } \\
\text { Marpaung }\end{array}$ \\
\hline
\end{tabular}


KLINIK TANJUNG KECAMATAN DELI TUA KABUPATEN DELI SERDANG PROVINSI SUMATERA UTARA TAHUN 2020

HUBUNGAN KOMUNIKASI TERAUPEUTIK DENGAN INTENSITAS NYERI PADA PERSALINAN PRIMIGRAVIDA INPARTU

9 KALA I DI KLINIK BERSALIN NINING PELAWATI LUBUK PAKAM KABUPATEN 36.13\% $\begin{gathered}\text { Tidak } \\ \text { Memenuhi }\end{gathered} \quad 0.1035 \quad \begin{gathered}\text { Afnan Sri } \\ \text { Wulan Gea }\end{gathered}$ DELI SERDANG PROVINSI SUMATERA UTARA TAHUN 2020

FAKTOR-FAKTOR YANG MEMPENGARUHI PEMBERIAN KOLOSTRUM PADA BAYI BARU

10 LAHIR DI KLINIK MADINA KECAMATAN MEDAN TEMBUNG KOTA MEDAN PROVINSI SUMATERA UTARA TAHUN 2020

PENGARUH PEMBERIAN MADU TERHADAP PENURUNAN INTENSITAS NYERI MENSTRUASI PADA WANITA REMAJA DI

11 KLINIK HJ. ROSDIANA KABUPATEN DELI SERDANG PROVINSI SUMATERA UTARA TAHUN 2020

PENGARUH SENAM ABDOMINAL
STRECHING EXERCISE TERHADAP

12 PENURUNAN DISMINORHEA PADA REMAJA PUTRI DI SMA RK KECAMATAN DELI TUA KABUPATEN DELI SERDANG PROVINSI SUMATERA UTARA TAHUN 2020

PENGARUH PEMBERIAN SUSU KEDELAI TERHADAP PENINGKATAN PRODUKSI ASI

13 PADA IBU NIFAS DI KLINIK KASIH IBU KECAMATAN DELI TUA KABUPATEN DELI SERDANG PROVINSI SUMATERA UTARA TAHUN 2020

PENGARUH ANEMIA DAN KEKURANGAN ENERGI KRONIS PADA IBU HAMIL DENGAN

14 KEJADIAN BBLR DI KLINIK NINING PELAWATI KEC.LUBUK PAKAM KAB.DELI SERDANG PROV. SUMATERA UTARA TAHUN 2020

HUBUNGAN RIWAYAT HIPERTENSI DENGAN KEJADIAN PRE EKLAMPSI PADA

15 IBU BERSALIN DI RSU.SEMBIRING KEC.DELI TUA KAB.DELI SERDANG PROVINSI SUMATERA UTARA TAHUN 2020

EFEKTIFITAS PENERAPAN HIPNOBIRTHING DALAM PENURUNAN TINGKAT MENJELANG PERSALINAN PADA IBU

16 PRIMIGRAVIDA DI KLINIK EKA SRI WAHYUNI KECAMATAN MEDAN TEMBUNG KOTA MEDAN PROVINSI SUMATERA UTARA TAHUN 2020 PENGARUH PEMBERIAN KEMBANG SEPATU TERHADAP PENURUNAN SUHU TUBUH

17 PADA PUSKESMAS KECAMATAN NAMORAMBE KABUPATEN DELI SERDANG $35.62 \% \quad$ Memenuhi 0.1035

Khamalia Syafaisyah

$\begin{array}{lllc}34 \% & \text { Memenuhi } & 0.1292 & \begin{array}{c}\text { Miftania } \\ \text { Rerimna Br } \\ \text { Sembiring }\end{array} \\ 33.55 \% & \text { Memenuhi } & 0.1125 & \begin{array}{c}\text { Sri Endang } \\ \text { Marpaung }\end{array}\end{array}$

$33.47 \% \quad$ Memenuhi $\quad 0.1385 \quad \begin{gathered}\text { Sri Endang } \\ \text { Marpaung }\end{gathered}$

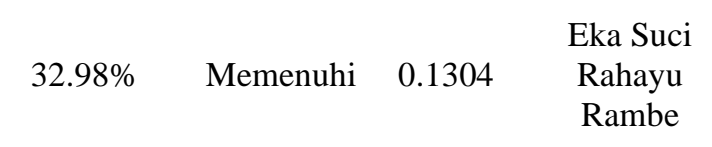
$32.22 \% \quad$ Memenuhi $\quad 0.1145 \quad$ Sri Endang Marpaung PROVINSI SUMATERA UTARA TAHUN 2020 
Persentasi

Kemiripan
Pemilik Judul

Laporan

Akhir Pada

Data Training

\begin{tabular}{|c|c|c|c|c|c|}
\hline & PEMBERIAN & & & & \\
\hline 18 & \begin{tabular}{llrr} 
MENYUSUI DINI & \multicolumn{2}{c}{ TERHADAP } & KEJADIAN \\
HIPOTERMI PADA & BAYI BARU & LAHIR DI \\
KLINIK CAHAYA & I LUBUK & PAKAM \\
KABUPATEN DELI & SERDANG & PROVINSI \\
SUMATERA UTARA TAHUN 2020 &
\end{tabular} & $26.02 \%$ & Memenuhi & 0.1171 & $\begin{array}{c}\text { Ernawati } \\
\text { Saritua } \\
\text { Tarihoran }\end{array}$ \\
\hline 19 & $\begin{array}{l}\text { HUBUNGAN TEKNIK PIJAT EFFLAURAGE } \\
\text { DENGAN PENURUNAN NYERI PERSALINAN } \\
\text { KALA I DI KLINIK BERSALIN NINING } \\
\text { PELAWATI LUBUK PAKAM KABUPATEN } \\
\text { DELI SERDANG PROVINSI SUMATERA } \\
\text { UTARA TAHUN } 2020\end{array}$ & $25.28 \%$ & Memenuhi & 0.1098 & Wiwanti Gea \\
\hline 20 & 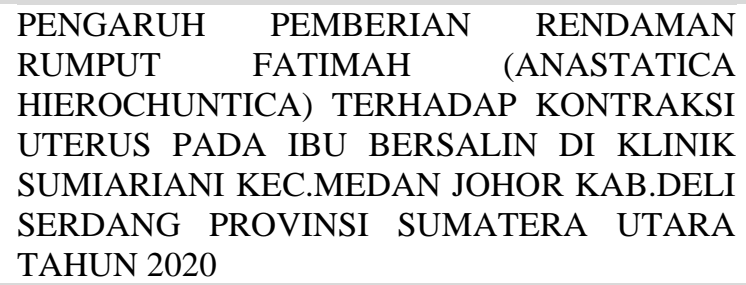 & $24.94 \%$ & Memenuhi & 0.1474 & $\begin{array}{c}\text { Shafira Wida } \\
\text { Sari }\end{array}$ \\
\hline 21 & 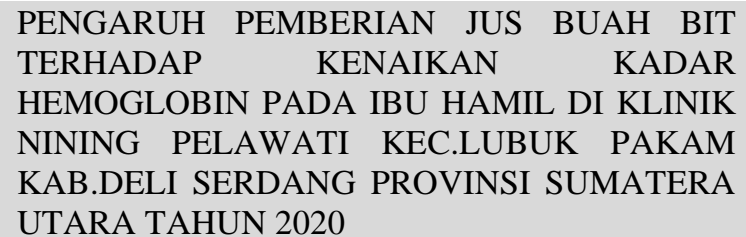 & $24.28 \%$ & Memenuhi & 0.1247 & $\begin{array}{c}\text { Dewi } \\
\text { Wahyuni }\end{array}$ \\
\hline
\end{tabular}

Data validasi di menggunakan ambang batas pada hasil kemiripan yang muncul saat dilakukan uji cob ajika hasil kemiripan =36 maka judul laporan tugas akhir tersebut di katakana tidak layak untuk di jadikan laporan tugas akhir. Sehingga hasil untuk validasi data uji latih tersebut maka di temukan judul laporan tugas akhir memiliki persen kemiripan melebihi ambang batas sebanyak 9 judul ataw $43 \%$ dikatakan tidak memenuhi dan 12 judul ataw 53\% dikatakan memenuhi.dan hasil dari waktu yang di capai memiliki rata-rata 0.12117 dalam menit.

\section{KESIMPULAN}

Dengan uji latih dengan metode Cosine Similarity dan Pembobotan TF-IDF pada kalimat judul laporan tugas akhir waktu yang efektif dengan rata 0.12117 dalam menit, sehingga akan menghemat waktu dalam menentukan memenuhi ata tidaknya judul laporan tugas akhir tersebut. Dan denagn metode ini pengguna yaitu prodi menjadi lebih evesien dalam pengesahan judul sehingga mengurangi kemiripan isi dari laporan tugas akhir mahasiswa.

\section{UCAPAN TERIMAKASIH}

Terima kasih disampaikan kepada pihak kampus Institut Kesehatan Deli usada yang telah mendukung terlaksananya uji coba pada penelitian ini.

\section{REFERENCES}

[1] R. T. Wahyuni, D. Prastiyanto, dan E. Supraptono, “Jurnal Teknik Elektro,” J. Tek. Elektro, vol. 9, no. 1, hal. 18-23, 2017.

[2] Z. Efendi dan M. Mustakim, "Text Mining Classification sebagai Rekomendasi Dosen Pembimbing Tugas Akhir Program Studi Sistem Informasi," Semin. Nas. Teknol. Inf. Komun. dan Ind., vol. 0, no. 0, hal. 235-242, 2017.

[3] P. Meilina, "Penerapan Data Mining dengan Metode Klasifikasi Menggunakan Decision Tree dan Regresi," J. Teknol. Univ. Muhammadiyah Jakarta, vol. 7, no. 1, hal. 11-20, 2015.

[4] D. H. Wahid dan A. SN, "Peringkasan Sentimen Esktraktif di Twitter Menggunakan Hybrid TF-IDF dan Cosine Similarity," IJCCS (Indonesian J. Comput. Cybern. Syst., vol. 10, no. 2, hal. 207, 2016, doi: 10.22146/ijccs.16625.

[5] C. F. Suharno, M. A. Fauzi, dan R. S. Perdana, "Klasifikasi Teks Bahasa Indonesia Pada Dokumen Pengaduan Sambat Online Menggunakan Metode K-Nearest Neighbors Dan Chi-square," Syst. Inf. Syst. Informatics J., vol. 3, no. 1, hal. 25-32, 2017, doi: 10.29080/systemic.v3i1.191.

[6] D. Susandi dan U. Sholahudin, "Pemanfaatan Vector Space Model pada Penerapan Algoritma Nazief Adriani , KNN dan 
ISSN 2614-5278 (media cetak), ISSN 2548-8368 (media online)

Available Online at https://ejurnal.stmik-budidarma.ac.id/index.php/mib DOI 10.30865/mib.v5i2.2935

Fungsi Similarity Cosine untuk Pembobotan IDF dan WIDF pada Prototipe Sistem Klasifikasi Teks Bahasa Indonesia," J. ProTekInfo, vol. 3, no. 1, hal. 22-29, 2016.

[7] O. Nurdiana, J. Jumadi, dan D. Nursantika, "Perbandingan Metode Cosine Similarity Dengan Metode Jaccard Similarity Pada Aplikasi Pencarian Terjemah Al-Qur'an Dalam Bahasa Indonesia," J. Online Inform., vol. 1, no. 1, hal. 59, 2016, doi: 10.15575/join.v1i1.12.

[8] J. Oliver, "Bab Ii Tinjauan Pustaka Aplikasi," Hilos Tensados, vol. 1, no., hal. 1-476, 2019.

[9] W. Issues, W. Issues, dan U. Words, “TESIS BAB 1 ( Repaired )," vol. 1, hal. 1-28, 2020.

[10] D. A. R. Ariantini, A. S. M. Lumenta, dan A. Jacobus, "Pengukuran Kemiripan Dokumen Teks Bahasa Indonesia Menggunakan Metode Cosine Similarity," J. Tek. Inform., vol. 9, no. 1, hal. 1-8, 2016, doi: 10.35793/jti.9.1.2016.13752.

[11] S. Sanjaya, S. Sanjaya, dan E. A. Absar, "Pengelompokan Dokumen Menggunakan Winnowing Fingerprint dengan Metode K-Nearest Neighbour," J. CoreIT J. Has. Penelit. Ilmu Komput. dan Teknol. Inf., vol. 1, no. 2, hal. 50-56, 2015, doi: 10.24014/coreit.v1i2.1229.

[12] R. Yulianti, Implementasi Penilaian Pembelajaran Berbasis Computer Based Test (CBT) di SMA Yadika 6 Tangerang Selatan. 2019.

[13] A. Deolika, K. Kusrini, dan E. T. Luthfi, “Analisis Pembobotan Kata Pada Klasifikasi Text Mining,” J. Teknol. Inf., vol. 3, no. 2, hal. 179, 2019, doi: 10.36294/jurti.v3i2.1077.

[14] M. Z. Naf' an, A. Burhanuddin, dan A. Riyani, "Penerapan Cosine Similarity dan Pembobotan TF-IDF untuk Mendeteksi Kemiripan Dokumen," J. Linguist. Komputasional, vol. 2, no. 1, hal. 23-27, 2019, doi: 10.26418/jlk.v2i1.17.

[15] A. Hidayat, "Impementasi Metode Term Frequency and Inverse Document Frequency Dan Marginal Relevance Untuk Monitoring Diskusi Online," vol. 13, no. 2, hal. 151-159, 2015.

[16] A. Khozaimi, S. S. Putro, dan M. Rohman, "Pengembangan Aplikasi Managemen Tugas Skripsi (Studi Kasus : Program Studi Teknik Informatika Universitas Trunojoyo Madura)," MATRIK J. Manajemen, Tek. Inform. dan Rekayasa Komput., vol. 18, no. 2, hal. 237-245, 2019, doi: 10.30812/matrik.v18i2.392.

[17] A. A. Prasanti, M. A. Fauzi, dan M. T. Furqon, "Klasifikasi Teks Pengaduan Pada Sambat Online Menggunakan Metode N- Gram dan Neighbor Weighted K-Nearest Neighbor ( NW-KNN ), $J$. 